\title{
Teacher Factors Influencing the Use of Ict in Teaching and Learning in South African Urban Schools
}

\author{
Prof E R Mathipa
}

College of Education Unisa Main Campus TvW Bldg. 6-57

Shirley Mukhari

Department of Language Education, Arts and Culture School of Education University of South Africa

\section{Doi:10.5901/mjss.2014.v5n23p1213}

\section{Abstract}

The is an explorative paper that is triggered by the imperative that; in terms of the South African National ICT Education Policy all teachers in all South African schools are expected to implement and integrate ICT to improve and enhance teaching and learning. Consequently many teachers find themselves in a situation in which they are caught with one foot in the future and another one in the past. The impact of globalisation, the need for 21 st century skills, the influence of information society and the diffusion and the ubiquitous nature of ICT in all spheres of life require teachers to employ ICT to improve the quality of teaching and learning in order to produce ICT capable learners who will be able to use ICTs for knowledge creation and knowledge sharing, social development and economic growth. This assumption is based on the New Network Society Theory which endorses the use of ICT in schools by all the stakeholders. This paper will share the qualitative data gathered through interviews with teachers who use ICT for the enhancement of teaching and learning in the urban schools of Gauteng province in South Africa. The results revealed that the factors impeding the integration of ICT in teaching and learning are: insufficient number of computers and lack of application programs, teacher generation gap, inadequate teacher training, lack of ICT skill and lack of confidence, teachers' beliefs, poor school leadership and lack of public support. The recommendations are wide ranging and include measures that will capacitate and encourage teachers to integrate ICT as prescribed by today's learner and social structure of the 21st century.

Keywords: Teacher- factors, ICT, teaching, learning, urban school

\section{Introduction}

Globalisation and the diffusion of ICT in all spheres of life have created a social system which is driven by knowledge and powered by technology. The prominence of ICT also puts the various education systems under pressure to use ICT in teaching and learning. Due to the explosion of knowledge, educational institutions including schools cannot continue as venues that transmit knowledge from the teacher to the learner or use the textbook as the only source of information. Schools are therefore expected to promote the acquisition of knowledge and skills through the use of new technologies to ensure efficient, continuous and lifelong learning. As a part of the global village, after 1994 the South African government introduced an education system which made provision for the same education for all South African learners. The policy also prescribed for the use of ICT by all schools to improve and enhance teaching and learning. This is endorsed by the policy statement (White Paper, 2004, GED, 2007) which stipulates that all South African learners must be ICT capable for the future. As part of the new social structure and the aspiration of making the South African Society an information society, computer laboratories with internet connectivity have been established in many urban schools to enhance and improve the quality of teaching and learning and to realise the national objective of the information society (White Paper, 2004).

Literature study (Tedla, 2012 and Makgato, 2012) reveal that the successful integration of ICT in teaching and learning largely depends on the availability of ICT infrastructure and teachers' adoption and embrace of ICT in education. Aktaruzzaman, Shamim and Clement (2011: 114) maintain that teacher competency is another indispensable variable to ensure the successful use of ICT in the teaching and learning environment. Despite the availability of computer laboratories and media centres in various urban schools, teachers indicated various issues that impede the use and the integration of ICT in their pedagogic activities. This paper focuses on these factors that prevent ICT usage in primary and secondary schools and makes recommendations that aim at capacitating and encouraging all teachers to use ICT with 
the intention of improving the quality of teaching and learning.

\section{Theoretical Framework}

This paper is underpinned by the Network Society framework which endorses the use of ICT in educational institutions with emphasis laid on ICT adoption by teachers who are faced with the task of teaching the net generation. Furthermore, the necessity of using ICTs for teacher development through community of practice and the networks established for knowledge acquisition and sharing played a role in the production of this paper. The advocates of the Network Society Theory maintain that new technology forms an inextricable part of the modern society and therefore through the utilisation of various ICT, the network members and the members of the global knowledge society are provided platforms to connect, to create together and share knowledge (Castells, 2000). According to this theory, all those who participate in the new knowledge economy need skills that will benefit them in terms of power, wealth and meaning in the information and knowledge society which can be facilitated and achieved through the use of various ICT tools. These digital tools also allow people all over the world to communicate with anyone, anywhere and at anytime without any face to face interaction. Siemens (2004) adds that members of the network use ICT to connect and use these ICTs to learn, share and distribute knowledge. These social networks are platforms in which collective knowledge become a source of individual knowledge and also become scenes for informal exchange of expertise which can benefit all who participate in the network.

The infusion of ICT in educational institutions as part of the new social structure has great implications for teaching and learning. This has resulted in transforming the traditional face to face teaching where the teacher was central in the teaching and learning environment. In this new social dispensation, the teacher's role is still to help learners to develop their skills and fulfil their potential for personal growth. The change due to the presence and prominence of ICT has led to a situation where the teacher is no longer the central figure who imparts knowledge to the learner. The envisioned education system is learner-centered where learners are in control of their learning, use the digital tools especially the internet to acquire and share knowledge with other learners in the network. Learner centerdness does not imply that teachers are relegated to the background. However, teachers still have the responsibility to facilitate teaching and learning and to improve their professional development by means of using various ICT tools. As facilitators and key figures in the classroom, teachers are expected to be digital competent in order to cope with the $21^{\text {st }}$ century skills that will enable them to produce learners who are able to create and share knowledge, who are problem solvers, have higher order thinking skills, can collaborate with other learners, can manage and control their learning. Castells (2000) calls learners with these qualities "the self programmable force" which is indispensable for personal, social and economic development.

The relevance of Network Society theoretical framework in this paper is based on the fact that for any society to develop optimally its education system must be founded on the knowledge and skills that are presently driving the network society. South Africa is such a society, thus, its mission and vision also finds expression in the South African Education Department in terms of the introduction of ICTs in teaching and learning. The South African ICT education policy endorses the view that ICTs be integrated across the curriculum and consequently Gauteng Department of Education devised a strategic plan for ICT use in schools and provided ICT infrastructure to actualise the envisaged transformation that is in accordance with the $21^{\text {st }}$ century demands for intellectual and social growth and for global competitiveness.

\section{Research Design and Method}

\subsection{Qualitative research design}

The qualitative design using the phenomenological approach was used in this research study in order to gain an in-depth understanding of the circumstances that inhibit the successful use of ICT in South African urban schools. Phenomenology is concerned with the study of experience from the perspective of the individual, bracketing all prejudgement. Phenomenological researchers have the responsibility to describe accurately the meanings of a lived experience or a phenomenon refraining from prejudgements but remaining true to the facts (McMillan and Schumacher, 2010; Groenewald 2004; Lester, 1999). The purpose of the phenomenological approach is therefore to illuminate or to identify the phenomena through the way they are perceived by the people involved in a particular situation. Groenewald (2004) concurs and states that the objective of the phenomenologists is to understand social and psychological phenomena from the perspective of people involved simply because data is contained within the perspectives of the actors in the situation. 
In phenemonologically based research, researchers can use a variety of data gathering instruments such as interviews, conversations, focus meeting and participant observation. These probing methods afford the researchers an opportunity to seek more information.

In this research endeavour, the researchers have used this approach in order to start from a perspective free from preconceptions to describe the challenges which urban school teachers face in integrating ICT in teaching and learning. The in-depth, face to face, interview was conducted with teachers and principals from various primary and secondary school in Mamelodi Township which falls under the jurisdiction of Tshwane North District in order to collect data. As indicated by phenomenologists (McMillan and Schumacher, 2010, Babbie, 2010, Creswell, 2007) the interview elucidated deep issues and made the teachers' voices heard. The warmth and the rapport between the researchers and the participants made the participants to open up and freely expressed their views on ICT usage in teaching and learning.

\subsection{Description of the sample}

A total of 6 teachers and 4 principals were purposefully selected to participate in the face-to face interviews. Of the 4 principals, 2 were primary school principals and 2 were secondary school principals. 3 teachers were primary school teachers and the other 3 were secondary school teachers. The teachers interviewed are those teachers who are in charge of the media centers and computer laboratories in their respective schools and they use these facilities for pedagogic and administrative purposes. These participants were interviewed individually so that their responses could be independent and uninfluenced by one another. All the interviews were audio recorded in May 2014 and transcribed for analysis.

\subsection{Research question}

The ICT policy of the National Department of Education in South Africa maintains that ICT must be integrated across the curriculum in order to create new ways for learners and teachers to gather and analyse information and to improve and enhance teaching and learning in all South African schools (DoE, 2004). Many schools especially in the urban areas are equipped with computers and some teachers have received training on the use of computers in delivering their subject matter. However, these ICT tools are not used effectively. The under or non-utilisation of ICT tools in the school environment constitutes a concern that initiated the paper. The research question that emanated from this situation is formulated as follows:

- Which factors prevent teachers from integrating ICT in teaching and learning in urban schools?

\subsection{Research Aim}

In view of the research question stated above, the objective of this research study is stated as follows:

- To determine the factors preventing teachers from integrating ICT in teaching and learning in urban schools.

\section{Literature Review}

\subsection{The significance of ICT in teaching and learning}

There is substantial evidence that ICT is an integral part of the global society and its value in schools is to help in knowledge creation, knowledge sharing, problem solving, communication, group and cooperative learning, the development of economic and social change. Tedla (2012) states that new technologies have the potential to promote and to transform teaching and learning processes. He furthers asserts that ICTs also provide effective teaching-learning atmospheres by providing opportunities for effective communication between teachers and learners. These new technologies also help learners in the development of knowledge and skills, cooperation, communication and problem solving. This is confirmed by Tay, Lim, Lim and Ling Koh (2012) who found that with ICT, the primary school teachers were able to use a variety of pedagogical approaches which included transmissive, dialogic, constructionist approaches to allow learners in their English class to construct their own digital stories, engage in dialogues and exchanges through the comments posted in discussion blogs. Tay et al (2012) also discovered that the use of drill and practice in mathematics enabled learners to master basic computational and arithmetic skills and the immediate feedback worked as motivational source for more engagement in the learning activities. The authors concur with the findings of these researches since in our modern times, ICT is ubiquitous in all spheres of life and forms part of the youth's culture. Various 
ICTs are used for entertainment, social communication, searching, transmitting and sharing knowledge. Siemens Computer and cell phone games help in developing those desired skills such as problem solving, which are expected to be mastered by learners.

Therefore, this is indicative that when ICT are used appropriately by enthusiastic and astute teachers, learners with different learning styles and particular needs can be assisted to manage their learning and to master the subject matter at their own pace. Over and above, ICT are also indispensable in teaching and learning as they provide access to information and provide learning beyond the classroom. Castells (2010) adds that learners should use new ICT to access knowledge in order to be powerful as knowledge is equated with power. The use of the internet by learners for example, can be a source of reference and a means of communication with peers and the experts. In underdeveloped and developing countries, ICT offer unprecedented opportunities to promote and enhance educational systems and reduce the sense of isolation thereby providing access to knowledge in ways that were unknown before.

Many researchers, who affiliate to the information society paradigm, agree that the climax of ICT usage in education is their potential to create the self programmable force for the workplace in order to be able to compete at a global level with anyone, anywhere and at any time (Aktaruzmann et al, 2011; Castells, 2010). It is therefore imperative that teachers employ ICT to be able to teach digital children and acquire new ways of teaching and learning which are considered to be relevant in the modern era which is powered by the use of new technologies.

\subsection{Why teachers should use ICT}

The benefits of ICT usage in the preceding paragraph are indicative of why some teachers integrate ICT across the curricula. The advocates of ICT in education (Eze and Olusola, 2013; Castells, 2000) assert that ICT in the classroom are essential for the provision of opportunities to enable learners to operate in the information society since the traditional methods of teaching do not prepare the learners to be productive. Today's teachers also face a challenge of teaching 'the Net Generation' which actually come to class equipped with multimodal skills who are constantly in touch, motivated by and responding to the ever changing worlds. These learners have the ability to use any technology they come across. Teachers therefore have to change their attitudes and beliefs as far as the teaching activities are concerned and adopt technology in order to perform the pedagogic activities with ease and confidence. Research studies (Eze \& Olusola, 2013) also reveal that teachers use ICT to expand pedagogical resources available and to facilitate knowledge sharing with fellow teachers. As much as ICT help learners in completing their educational tasks, ICT also give teachers an opportunity to help learners with particular needs. Tedla (2012:) and Tay et al(2012) confirm that teachers use ICT tools in order to make the lessons more interesting and engage learners according to learners' potentials. The exposure in utilising various digital tools also encourages learners to reinforce the learnt material using the individual learning styles. Over and above this, it is beneficial to learners from digitally poor backgrounds as they are provided with the opportunity of being included in the use of ICTs for knowledge sharing and in making the world flat by enabling global communication with anyone, anytime and anywhere.

According to Hennessy, Harrison and Wamakote (2010: 41), most Nigerian teachers who use new technology in teaching and learning, expressed the view that ICT is very useful and also stated that ICT make teaching and learning easier. In other underdeveloped and developing countries, the use of ICT is considered as a foreign idea and borrowed policies. These borrowed ICT ideas are adapted and integrated into their policies to work successfully but in many instances are found to be impractical and are bound to fail. This failure is due to the fact that many African states do not have funds to sustain the use of ICTs in their schools. In the Sub Saharan region where ICT use in teaching and learning is deemed important, the integration is not fully utilized as expected and experienced in the well developed countries. Research results (Makgato, 2012) indicate that teachers do not use ICTs due to the fact that they are afraid of new innovations and change and are technophobic despite the the availability of ICTs in their schools. In many instances lack of technological skills is another contributor in non-use of ICT in teaching and learning. Some teachers shun ICT and continue to use traditional methods of teaching and learning, and as such limit the use and importance of ICT.

Research has proven that teachers are key figures for the successful integration of ICT in teaching and learning and are also agents of change. The use of ICT is to a large extent dependent on them. However, Eze and Olusola (2013) reiterate that the role of the teacher is changing as ICT are inventing new roles for teachers. They further assert that through ICT some resources such as overhead projectors and chalkboards are becoming redundant and obsolete when learners have access to the same networked resource on which the teacher is presenting the information. Teachers' role of transmitting knowledge is also seen as being replaced by encouraging learners to construct their own knowledge, engage in problem solving activities, develop critical thinking skills, using the internet to search and select the required information, fostering collaborative work for peer teaching, knowledge sharing and social interaction. 


\subsection{Factors influencing ICT integration in teaching and learning}

Researchers identify various kinds of factors that inhibit the use of ICT in the classroom. According to Sang et al (2010), Tedla (2012) and Tay (2011) there are two types of barriers that impede the integration of ICT in teaching and learning and are described as school characteristics or external barriers and teacher characteristics or the internal barriers. The school characteristics are factors that are perceived as major obstacles and comprise inadequate access to ICT, internet connectivity, technology related training, ICT policy and time whereas the teacher characteristics include teachers' beliefs, confidence, ICT skills and teachers' attitudes towards ICT. These variables are interrelated and consequently the success of or the failure of the implementation of ICT in teaching and learning does not depend on one individual factor but it is a process which involves a set of interrelated factors (Tay et al: 2012; Tedla, 2012).

\subsubsection{Teacher- level barriers:}

- Lack of confidence: Many researchers indicate that lack of teacher confidence is a barrier that prevents teachers from implementing ICT. Anxiety and fear of failure while using ICT in a class of learners who already know more about the operation of these ICT tools is posing a big challenge.

- Lack of teacher competence: Researchers (Tedla: 2012; Bingimlas; 2009) assert that another barrier related to lack of confidence is the lack of competence in teachers. Lack of technological knowledge and skills to use ICT prevent teachers from implementing ICT in their teaching activities.

- Resistance to change and negative attitude: Change is commonly not an easy thing that will take place smoothly because it is something unusual and frightening. Old teachers who are comfortable with the traditional way of teaching do not want new and innovative methods of teaching. They are stuck with the faceto-face teaching and teacher centered methods which gives them the sense of power in front of their learners (Makgato: 2012:109). Some teachers who resist ICT in teaching and learning believe that ICT have no benefits for themselves and their learners. The use of ICT in some countries is regarded as unholy and is against the people's religion. Sang, Valcke, Van Braak, Tondeur and Zhu (2010) also assert that teacher's positive attitude and constructivist beliefs towards ICT is a big determinant of integrating ICT in teaching and learning.

\subsubsection{School-level barriers}

- Lack of access: Another complex barrier is lack of access to ICT resources and lack of internet connectivity. In some Nigerian schools, computers are shared and therefore had to be booked in advance. Those teachers who could not do so or those who forgot to make the bookings were denied access to those computers (Hennessy et al 2010). In African states most computers are of poor quality as they are donations from the business companies. Lack of educational hardware is also a major problem that prevents both teachers and learners from using ICT in teaching and learning. Eze and Olusola (2013) state that in Botswana, lack of electricity in rural schools and the high cost of computers is a stumbling block to the integration of ICT. Internet connectivity is still impossible where there are no telephones and electricity. Kort and Husing (2007) also found out that a third of European schools do not have broadband internet access.

- Lack of time: Some researchers have found that competent teachers in terms of ICT usage in teaching and learning make little use of ICT and attribute that to lack or insufficient time. Studies carried out in Saudi Arabia by Sicilia (2005) indicate that Saudi teachers work from 7.00 in the morning until 2.00 p.m and have limited hours to integrate ICT into their science education.

- Lack of effective training: Little or lack of professional training on how to use ICT in education is a major barrier. According to Tedla, (2012); in-service teachers indicated that lack of training is also due to lack of time as teachers have limited hours to integrate ICT in the activities. Providing pedagogical training on using ICT across the curriculum is an important issue which will enable teachers to succeed in teaching 'Net Generation' who in turn are to meet the 21st century skills and become members of the information society.

\section{Discussion of Results}

The analysis of the various interviews yielded a wide spectrum of views and perspectives and paints a comprehensive 
picture of how teachers see and regard the role of ICT in teaching and learning. The prominence of ICT in South African schools is seen as an opportunity to transform the nature of education but the teachers identified issues that prohibit the integration of ICT in their respective schools. These factors are not different from those that are experienced by teachers in the developed and under-developed countries. The various themes are mentioned in the subsequent paragraphs.

\subsection{Computers and other hardware}

The number of computers available for use by learners is less than the number of pupils in the class. This is a concern expressed by all teachers due to overcrowding. Teachers expressed that it is impossible for each learner to have his or her own computer and consequently they are grouped to work on one computer at a time. Although cooperative learning is encouraged, sometimes other learners do not participate to the full extent and are always in the background leaving the active ones to take the lead in their educational activities. This factor is consistent with inadequate access to ICT infrastructure as pinpointed in the literature review.

\subsection{Internet connectivity}

Internet connectivity is available and provided to all schools by Gauteng online. The big hiccup is brought about by the termination of the Gauteng online contract by the Department of Education since the tablets with the educational software are distributed to GED schools. However there is uncertainty among teachers and principals about the insufficient number of tablets for each school as well as the internet connectivity which enables networking and teachers' participation on communities of learning.

\subsection{Technophobia}

The non-use of ICT by the older generation of teachers came out as a major obstacle that impedes ICT integration in teaching and learning. It emerged during the interviews that older teachers believe that ICTs are not meant for them; as a result they are anxious and are afraid of using ICT for teaching and learning. Some old teachers do not know how to reconcile ICT and the subject matter. Expressions such as teachers being technophobic were used to describe all teachers who do not integrate ICT in their lessons. This factor acknowledges the teacher generation gap highlighted in the literature study.

\subsection{Lack of digital skills}

Lack of digital skills was also cited as a factor. Teachers are said to be afraid of ICT because they do not know how to use these gadgets. The teacher participants who were interviewed indicated that they had skills and are competent as far as ICT usage in teaching and learning is concerned and can interact with the in-housed contents which they use for their learners.

Many teachers indicated that they received inadequate training on the use of ICT. The duration of the training they have received varies for 15 minutes and one week. 4 teachers mentioned that they were satisfied with the nature of training they had received because of the interaction with St Alban's College, enrolment at the University of Pretoria and during teacher training. The ones who were well trained are fearless and expressed that they are very confident and engage learners in different ICT activities. They mentioned that ICT proved to be a better methodological resource because learners are active in the learning process, information is readily available and the immediate feedback plays an important role in raising interest and motivating learners to partake in their learning activities.

\subsection{Poor leadership and the absence of school's ICT}

Poor leadership and the absence of school's ICT policy are some of the factors that do not endorse the use of ICT in the school environment. One primary school teacher indicated that their computer laboratory is not functional because it is controlled by the teacher and the SMT and they do not understand the significance of computers. She further mentioned that the laboratory is always locked even during school hours. All teachers mentioned that there are no ICT policies at their schools, consequently teachers are not obliged to integrate and implement ICT in their activities. One teacher mentioned that he just slots ICT periods in the school timetable where there are free periods so that he can have ample time in the computer laboratory with his pupils. 


\subsection{Vandalism and burglary.}

Criminality in some of the urban schools is one big issue that destabilises education. Most teacher participants reported that on several occasions their computer laboratories were burgled and computers and printers were stolen. In one high school the flat screen TV was stolen and learners are unable to tune in for enrichment lessons.

Teachers also expressed concern about the technical support. They mentioned that the Department of Education takes long to repair or to replace damaged computers and other ICT tools. Such delays also hamper the progress of both teachers and the learners.

\subsection{Poor parental involvement}

Teachers reported that many parents are not so concerned about their children's education and perhaps due to poverty and illiteracy, many learners do not have access to ICT at home. One female teacher indicated that sometimes she request parents to lend their children their smart phones in order to do some activities and that helps encourage parents to provide the necessary ICT tools seeing that they do benefit their children educationally. The same teacher uses her laptop for social communication with learners from other places and this gesture delights both her pupils and their parents.

Teachers also mentioned that they use ICT to get more recent information on personal and professional development.

As far as the benefits of ICT in teaching and learning are concerned, many teachers talked about motivation, better performance, arousing interest, searching and finding information on the internet, learning at own pace, cooperative and group activities, boosting learners' confidence.

\section{Conclusion and Recommendations}

Research has indicated and continues to show that indeed ICT have the potential to revolutionise the quality of education but the availability of ICT infrastructure in schools is futile if teachers lack the knowledge and the skills on how to use these instruments to deliver their subject matter and to engage learners through ICT. Although there are various educational issues which prevent teachers from implementing ICTs in the teaching activities. Research findings (Chigona, Chigona, Kausa, 2012; Lundall and Powell, 2000) reiterate that the role of the teacher is of great importance in ensuring that ICTs are used in an educational situation. All identified teacher related and school related challenges must be overcome in order to ensure the successful integration of ICT in teaching and learning. Recommendations for the appropriation of ICTs by teachers to enhance their pedagogical activities are summarised as follows:

- Adequate training opportunities for all teachers must be prioritised by the Department of Education to enable teachers to get to grips with new technologies which can impact and enhance teaching and learning.

- The teachers must be encouraged to consult ICT competent teachers for help and work collaboratively with peers in order to learn from their expertise and experiences as asserted by Hennessy et al (2010). Kopp, Matteucci and Tomasetto (2012) also talk of virtual collaboration which is significant in e-learning.

- The online teacher development communities need to be introduced for support, sharing of knowledge and discussion pertaining to teachers' activities especially those that entail ICT integration. The absence of ICT policy at school level is major setback. Each school must have its ICT policy which will endorse the use of ICT by all teachers at school.

- Teachers also need to be conscientised on how these new ICT can be used as better methodological resources which will benefit both their colleagues, learners and the society at large as anticipated for the creation of a knowledge society.

\section{References}

Aktaruzamzaman, M.D, Shamim. R.H and Clement CK. 2011: Trends and Issues to integrate ICT in teaching Learning for the future world of Education. International Journal of Engineering \& Technology IJET-IJENS Vol: 11 No 03.

Babbie, E.2010: The practice of Social Research (12th edition). Belmont, CA: Wadsworth

Bingimlas, K.A. 2009: Barriers to the successful integration of ICT in teaching and learning environments: A Review of the literature. Eurasia Journal of Mathematics \& Technology Education, 2009, 5(3), 235-245.

Castells, E. 2000: Materials for an exploratory theory of the network society. British Journal of Sociology 51 (1), 5-24. 
Creswell, J. W. 2007. Qualitative Inquiry \& Research design: Choosing among five approaches. Second edition, SAGE Publications: London.

Department of Education: 2004: White Paper on e-Education. Notice 1869 of 2004 in Government Gazette No 236734 of 26 August 2004.

Eze, R.I and Olusola E. 2013: The teachers and the use of ICT for professional development. International Conference on ICT for Africa: 2013:

Groenewald, T. A phenomenological Research Design Illustrated: 2004. Internationla Journal of Qualitative Methods 3 (1) April, 2004. Retrieved from http://www.ualberta.ca/ iiqm/backissues/3/1/pdf/groenewald.pdf.

Hennessy, S, Harrison, D and Wamakote L. 2010: Teacher Factors influencing Classroom use of ICT in Sub-Sahara Africa Itupale Online Journal of African Studies, 2(2010) 39-54.

Hennessy, S, Ruthven, K and Brindley S: 2007: Teachers' perspectives on integrating ICT into subject teaching: Commitment, constraints, caution and change.

Kopp, B, Matteucci, CM and Tomasetto, C. 2012: E- tutorial support for collaborative online learning: An explorative study on experienced and inexperienced e-tutors. Computers \& Education 58 (2012) 12-20.

Lester, S. An introduction to phenomenological research. 1999. Retrieved from www.sld.demon.co.uk/resmethy.pdf

Makgato, M. 2012. Status of teachers' use of educational technology: a case of some schools in South African semi-urban locations DOI: 10. 7763/PEDR. 012 V 47. 23.

McMillan, J.H and Schumacher, S. 2010: Research in Education: Evidence-based Inquiry. Seventh Edition. Pearson.

Sang, G; Valcke, M. Van Braak, J. Tondeur, J. and Zhu, C. 2010: Factors associated with the integration of ICT into Chinese primary school classrooms: An interplay of teacher-related variable.

Siemens, G. 2004. A learning theory for the digital age. Retrieved from http/www. Elearnspace.org/articles/connectivism. Htm.

Tay, L.Y. 2011: Integrating the technological Dimension into teaching and Learning - A Sociocultural Perspective.

Tay, L.Y, Lim, S. K; Lim C.P and Ling Koh, J.H: 2012. Pedagogical approaches for ICT integration into primary school English and Mathematics: A Singapore case study)

Tedla, B A. 2012. Understanding the importance, Impacts and Barriers of ICT on Teaching and Learning in East African Countries. International Journal for e-learning Security (JeLS), Volume 2, Issues 3/4, September/December 2012. 